\title{
Resztki awangardy. Powojenne pisma filmowe Tadeusza Peipera
}

\author{
Leftovers of the Avant-Garde. Postwar Film Writings of Tadeusz Peiper
}

\begin{abstract}
Postwar film writings of Tadeusz Peiper are the protest against "the policics of the voice" (M. Dolar) of the Polish social realist and propaganda films. Escaping from be-ing involved in communist ideology, the author creates a cinematic theory concentrated on nonverbal elements. An important role is played by categories extremely far from the constructivist discourse of art (nostalgia, community, non-human).
\end{abstract}


* Katedra Wspólczesnej Literatury i Kultury Polskiej, Instytut Filologii Polskiej UMCS Pl. Marii Curie-Skłodowskiej 4A/205, 20-031 Lublin

e-mail: aleksander.wojtowicz@poczta.umcs.lublin.pl 
Filmowe pisma Tadeusza Peipera powstawały w czasie, kiedy niedawny „papież awangardy" porzucił literaturę i skupił się na sztukach widowiskowych. Zwrot ten miał dramatyczne podłoże, z jednej strony wiązał się z ciężkimi doświadczeniami, jakich los nie szczędził mu podczas lat wojny spędzonych niemal w całości na terenie Związku Radzieckiego, z drugiej natomiast - sprzęgnięty był z chorobą, która dręczyła go od dłuższego czasu. $Z$ tego względu powojenne szkice odczytywane były przez Jarosława Fazana w perspektywie poetyki schizofrenicznej, czemu patronowało przekonanie, że „antropologiczny akcent krytyki powojennej Peipera wiąże się z jej rekonstrukcyjnymi celami osobistymi. Na scenie i na ekranie poszukuje on inscenizacji swojej — nieosiągalnej w rzeczywistości — tożsamości, szuka sposobów re-konstrukcji człowieka zdruzgotanego, rozproszonego na wojennych drogach" (Fazan 2010: 256).

Próby rekonstrukcji tożsamości korespondowały z odbudową kraju. Tuż po powrocie do kraju Peiper szukał dla siebie miejsca w krystalizującym się porządku państwowym, zabierał głos w sprawach związanych z budowaniem instytucji kultury, zgłaszał swój akces do działalności w rodzimej kinematografii, próbował być zarówno scenarzystą, recenzentem, jak i teoretykiem. Jego rozważania na ten temat nie były jedynie kontynuacją poglądów z międzywojnia (Kluszczyński 1983: 67-70). Rosnące znaczenie filmu w powojennej kulturze sprawiło, że bacznie śledził rozwój tego medium, szczególną uwagę zwracając na coraz większe możliwości techniczne. Dotyczyło to zwłaszcza dźwięku i barwy — ich coraz doskonalsze odzwierciedlenie na ekranie dawało namiastkę wiary w to, że zawarty przez awangardę i technikę sojusz wciąż obowiązywał, a jego rezultatem był nieustający progres $\mathrm{w}$ dziedzinie sztuki. Równocześnie formułował wiele nowatorskich pomysłów, dotyczących między innymi „przedstawień operowych na ekranie", kompozycji fabularnej, przewidywał także, że kiedyś „uniwersytety wlączą w krąg swoich prac także sztukę ekranową” (Peiper 2000: 610).

Ale jego powojenne pisma filmowe - $\mathrm{i}$ to jest główny temat niniejszego szkicu — stanowiły również świadectwo zderzenia indywidualnej wrażliwości z ustrojem autorytarnym. Rezultatem tej kolizji był rosnący dystans do ekranowego głosu, który przeistaczał się w narzędzie propagandy. $Z$ tego względu Peiper pisał o nim z widoczną rezerwą, która zaznaczała się już w pierwszych powojennych tekstach, a z czasem coraz bardziej się potęgowała, prowadząc niedawnego teoretyka awangardy w rejony sytuujące się na antypodach konstruktywizmu. 


\section{„Tyrańska mowa” i „ludzkie głosy”}

Dystans ten wyraźnie wybrzmiał już w tekście na temat twórczości „Czołówki Filmowej”. W recenzji krótkometrażówki Polska Walcząca Peiper dużo uwagi poświęcił strategiom estetycznym, jakimi autorzy posłużyli się do wyeksponowania potęgi militarnej Warszawskiej Dywizji Piechoty im. Tadeusza Kościuszki. Pisał o „narzędziach boju, które ukazują cały urok swej plastyki”, a także o „wspaniałych działach, wspaniałych czołgach, które suną jak olbrzymie pawie, pyszniące się swą mocą” (Peiper 2000: 448). W słowach tych pobrzmiewało nie tylko charakterystyczne dla dyskursu futuryzmu utożsamienie wojny z pięknem, lecz również konstruktywistyczny z ducha zachwyt maszyną, która służyła człowiekowi. Była to jednak „służba” radykalnie odmienna od tej, jaką dwie dekady wcześniej opiewał w opartym na utylitarnych hasłach manifeście Miasto. Masa. Maszyna (1922), bowiem realizowała się nie w codziennym życiu aglomeracji, lecz na polu bitewnym. Peiper komplementował twórców filmu za „sposób wprowadzenia na ekran wybuchów światła, towarzyszących wystrzałom działowym; w ich ujęciu wystrzały te impresjonują widza jako zjawisko ekranowe, a zarazem unaoczniają wysoki gatunek maszyn bojowych, które współpracują tu z ludźmi” (Peiper 2000: 448). Konstruktywistyczna retoryka obracała się tu we własne przeciwieństwo; współpraca maszyn z ludźmi nie tworzyła zrębów nowej cywilizacji, lecz dopełniała dzieła zniszczenia.

Rozważania Peipera były jednak dalekie od militarystycznego doktrynerstwa. Zachwyt nad stroną wizualną nie był równoznaczny z entuzjazmem dla całego filmu, który oceniał jako nierówny pod względem artystycznym i kompozycyjnym, krytykując zwłaszcza wypowiedzi lektora: „Film ten cechuje kronikarska rzeczowość. Tylko speaker jest w nim nierzeczowy. Ba, gdy mówi o żołnierkach, sypie komplementami. Stanowczo jednak za daleko posuwa swawolność, gdy symbol dzisiejszej Francji, literę V, zestawia z inicjałami W.W." (Peiper 2000: 450). Diagnozowana przez pisarza niewspółmierność pomiędzy porządkiem obrazów a towarzyszącym im komentarzem odsłaniała po części „piętę achillesową estetyki awangardy”, czyli „ślepotę na mechanizmy stylizacyjne rzeczywistości w imię ich rzekomo nagiej rejestracji, służącej współczesnym mediom” (Groys 2010: 46). Peiper pisał o „tyrańskiej władzy mowy speakera”, która zakłócała autentyzm reportażowego przekazu; „nawet pieśni naszych żołnierzy i marsze ich orkiestr skazane są na śmierć — przez zagłuszenie”, stwierdzał ironicznie, zarzucając jednocześnie autorom, że ich dzieło cechowała zaskakująca „obojętność dla ludzkich głosów” (Peiper 2000: 449). Ideologiczny ton zagłuszał głosy żołnierskiej wspólnoty, nie dając widzom szansy na wysłuchanie indywidualnych wypowiedzi jej szeregowych członków.

Przeciwstawienie „tyrańskiej władzy mowy” i „ludzkich głosów” ujawniło jeden z kluczowych tematów, jaki wyznaczał ramy powojennych rozważań Peipera na temat dzieł filmowych, które rozpatrywane były przez niego w ramach siatki korespondujących ze sobą opozycji: między egzystencją indywidualną a wspólnotową, sferą życia prywatnego a przestrzenią zawłaszczaną przez reżim polityczny, wreszcie - między indywidualną ekspresją a porządkiem ideologicznym narzucanym przez władzę. Perspektywa taka pozwoliła na wyeksponowanie procesu przenikania mechanizmów propagandowych do tkanki języka oraz struktur fabularnych wytworzonych na gruncie kultury popularnej. Dramatyzm poczynionych przez niego obserwacji potęgowały dwie kwestie; po pierwsze wyznający przed wojną socjalistyczne poglądy pisarz obserwował dewaluację tych ideałów w realiach pierwszych lat niepodległości,

$1 \quad$ Tj. Wanda Wasilewska. 
po wtóre - dręcząca go choroba wzmacniała poczucie wszechobecnego zagrożenia. Paradoksalnie jednak, daleko posunięta i podsycana przez paranoję podejrzliwość nie zawsze prowadziła do błędnej oceny rzeczywistości, niekiedy umożliwiła także jasną ocenę manipulacji stosowanych przez władzę.

Peiper z dużą przenikliwością opisywał mechanizmy zawłaszczania i deformacji języka. Tego rodzaju strategia wymagała sporej ostrożności, operowania niedomówieniami i aluzjami w odniesieniu do spraw, o jakich nie można było wówczas mówić wprost. Doszła na przykład do głosu w ostatecznie nieopublikowanym szkicu poświęconym Żołnierzowi zwycięstwa (1953, reż. W. Jakubowska), o którym pisał z dużą dozą krytycyzmu, dotyczącego nazbyt jednowymiarowej kreacji Karola Świerczewskiego, chybionych pomysłów kompozycyjnych oraz nie do końca przemyślanego scenariusza, podobne zresztą wskazywali inni komentatorzy, nawet podczas dyskusji o scenariuszu na posiedzeniach Wydziału Kultury KC PZPR (Krasucki 2007: 52). Chwalił natomiast reżyserkę za konsekwentne unikanie zbyt agitacyjnego tonu oraz fakt, że główny bohater „o sprawach publicznych na ogół nie mówi zdaniami utartymi”, czyli - mówiąc wprost - unika socrealistycznej retoryki, a „polityczne uzasadnienia jego działań wyjaśniają się głosami padającymi z otoczenia” (Peiper 2000: 473). A jednocześnie zauważał, że z tego schematu wyłamuje się scena, w której przedstawiony został dialog Świerczewskiego z Bolesławem Bierutem.

Rozmowa była popisem partyjnej nowomowy. Prezydent rozpoczynał tyradę od zdań, w których niepodzielnie panowała taka retoryka: „Zagadnienie czujności staje dziś w całej pełni przed każdym z nas i przed całą partią. Wróg wciąż liczy na to, że uda mu się oszukać masy. Liczy na wewnętrzne rozbicie. Wróg stawiał na Mikołajczyka i przegrał sromotnie. Ale byłoby wysoce niebezpiecznym sądzić, że odepchnięte od władzy klasy i ich zagraniczni opiekunowie wyrzekli się dalszej walki”. Wtórował mu generał, mówiący między innymi o konieczności „twardej postawy partii i kierowanych przez nią organów”, o wrogu, który „staje się mniej uchwytny i bardziej podstępny”, o „towarzyszach niewykazujących dostatecznej czujności" (Jakubowska 1953). W tej krótkiej, bo zaledwie dwuminutowej konwersacji, pojawiło się więcej klisz i właściwych nowomowie zwrotów niż w całym, ponad trzygodzinnym filmie.

Nie uszło to uwadze Peipera, który wzywał do wycięcia sceny. Propozycja ta przekraczała w swoim radykalizmie krytyczne uwagi innych recenzentów, wysuwających różne zastrzeżenia do sposobu, w jaki przedstawiony został Bierut (w momencie premiery Żołnierza zwycięstwa był on Przewodniczącym KC PZPR oraz Prezesem Rady Ministrów). Peiper przekonywał, że „ujemne wrażenie wywołuje rodzaj mowy obu rozmówców”, a w zdaniu, które ostatecznie przekreślił, dodawał: „Nie waham się twierdzić, że cała scena wypadła niedopuszczalnie kompromitująco, przy czym kompromituje również wszystkich obywateli państwa polskiego, kompromituje nas wszystkich" (Peiper 2000: 473). Dopisek ten wyraźnie ujawniał emocje, jakie towarzyszyły pisarzowi, wysuwającemu mocne oskarżenia zarówno pod adresem twórców filmu, jak i - pośrednio - systemu, który sankcjonował (bądź wymuszał) takie strategie dyskursywne. Ostra krytyka wulgarnej retoryki partyjnej temperowana była przez autocenzurę, zaś współistnienie tych sprzecznych tendencji było częścią szerokiego pola napięć determinujących ostateczny kształt jego tekstów o tematyce filmowej. 


\section{Przeciw „wyjaśniaczom”}

Alternatywą dla frontalnej krytyki było w powojennych tekstach Peipera milczenie. Symptomatyczna pod tym względem wydaje się zachowana w rękopisie (i nieopublikowana) recenzja Zakazanych piosenek (1946, reż. L. Buczkowski). Ten pierwszy powojenny film polski został wkrótce po premierze negatywnie oceniony przez wielu komentatorów (Hendrykowska 2011: 15-21), zwłaszcza przez publicystów „Kuźnicy”, między innymi Adama Ważyka, który zarzucał twórcom „zbyt słabe chęci do wyleczenia się z narowów przedwojennych” oraz — co brzmiało jeszcze poważniej — brak ukazania chwili, gdy bierny opór zamienił się w czynną walkę, „co jest przejściem historycznym dla każdego, kto rozumie historię” (Ważyk 1947: 15). Uwagi te, uzupełnione pryncypialnym stwierdzeniem, że „nie po to kinematografia polska wyszła poza sektor gospodarki prywatnej, aby dogadzać najtandetniejszym gustom publiczności”, wpisywały się w chór zarzutów, których presja była tak znaczna, że utwór przemontowano i zaprezentowano publiczności ponownie w 1948 roku, tym razem znacznie bardziej dostosowany do ideologicznych oczekiwań zwolenników obozu władzy.

Recenzja Peipera dotyczyła późniejszej wersji tej produkcji ${ }^{2}$. Być może to właśnie wprowadzone zmiany sprawiły, że ocenił Zakazane piosenki wręcz druzgocąco, choć - co znamienne - kierunek jego krytyki był inny niż w przypadku tekstu Ważyka. Rozważania Peiper skierował przeciw doktrynerskiemu porządkowaniu doświadczeń ostatnich lat, dlatego z dużym dystansem wypowiadał się o wprowadzeniu do kompozycji postaci „wyjaśniacza” (Roman Tokarski), który mówił o grozie lat wojennych i heroizował wykonawców tytułowych piosenek. Peiper wychwytywał niekonsekwencje tej narracji, a jednocześnie sugerował, że bagatelizowała dramatyczne wydarzenia: „Wyjaśniacz [...] nie jest w zgodzie z zawartością filmu, gdy twierdzi, że piosenki uliczne podnosiły na duchu. Nie widzimy tego i nie słyszymy. Bo to, że po klęsce powstania warszawskiego, gdy już pokazano nam bezsilne biegi, ciosy i strzały warszawskiej młodzieży i warszawskich dzieci, gdy pokazano nam płonące kawały miasta, walące się ściany domów i gruzy z nich pozostałe, to że tuż potem w czasie śpiewania piosenki bohaterka filmu mówi «wszystko w porządku», to - wcale nie jest w porządku" (Peiper 2000: 552-553). Słowa te nie odtwarzały dokładnie wspomnianego dialogu, bo cytowana tutaj kwestia wypowiedziana była przez Halinę Tokarską (Danuta Szaflarska), która opowiadała Tokarskiemu o samopoczuciu matki. Jednak cała scena, która rozgrywała się w piwnicy pełnej rozśpiewanych powstańców, nie licowała z grozą wydarzeń na powierzchni, co stworzyło niezamierzony kontrast pomiędzy „tam” a „tu”. Zresztą ciekawsze od pytania, co źle zapamiętał Peiper, wydaje się pytanie: co chciał zobaczyć w tej scenie? Powtórzmy: „bezsilne biegi, ciosy i strzały warszawskiej młodzieży i warszawskich dzieci” oraz "płonące kawały miasta”, nagą przemoc, okrucieństwo i widmo nieuchronnej klęski, mówiąc najkrócej: traumę wojny.

Zasygnalizowane wcześniej przeciwstawienie tekstów Peipera i Ważyka, czyli dwóch międzywojennych awangardzistów, odsłania przesunięcie, jakie dokonało się w tej formacji po przekroczeniu progu 1945 roku. Pierwszy z nich w latach powojennych porzucił postawę

2 W wersji z 1946 roku otwierająca film rozmowa miała wymiar metafilmowy, ponieważ odbywała się w atelier Filmu Polskiego, gdzie Roman Tokarski (Jerzy Duszyński), przedstawiający się jako amatorski kolekcjoner piosenek z czasu wojny, opowiadał o nich zebranym słuchaczom. Natomiast w wersji z 1948 - Roman Tokarski (także Duszyński) opowiadał o piosenkach zebranym w mieszkaniu osobom, między innymi Jurkowi (Feliks Żukowski), który lata wojny spędził w Anglii i z tego względu zupełnie nie rozumiał okrutnych okupacyjnych realiów. 
konstruktywistycznego piewcy utopii przyszłości i ze sporą rezerwą odnosił się do wprowadzanych w kraju zmian, natomiast drugi — jeszcze niedawno odrzucający poznawcze dogmaty nowator - przeistoczył się w ,inżyniera dusz”. Rola taka bynajmniej nie była zaprzeczeniem awangardowych założeń, lecz raczej ich aż nazbyt konsekwentną realizacją, ponieważ zbliżenie sztuki do praxis życia społecznego dokonywało się na podstawie warunków dyktowanych przez doktrynę marksistowską (Groys 2008: 146). To właśnie pod jej wpływem Ważyk dzielił artystów na nierozumiejących historii i tych, którzy potrafili przeniknąć jej znaczenie, a forsowana przez niego w recenzji Zakazanych piosenek idea „rozumienia historii” zbliżała go do doktrynerstwa. Peiper krytykował film z innej perspektywy. Założenie, że okupanci bali się jak ognia tytułowych piosenek, raziło naiwnością, co więcej — jego zdaniem sprawa miała się w sposób zgoła odwrotny, bo „uliczne piosenki, gloryfikowane przez autorów filmu, były w gruncie rzeczy wybrykami o skutkach bolesnych społecznie" (Peiper 2000: 552). Jego zdaniem rozliczenie z traumą wojny wymagało od kinematografii zupełnie innego języka wrażliwości niż ten operujący piosenkami, które niekiedy — jak stwierdzał w dość jednoznaczny sposób - podnosiły na duchu „głupawo”. Jednocześnie nie odmawiał im walorów emocjonalnych, „tekst i melodia tych śpiewów” - pisał w nieco protekcjonalnym tonie - „mogą być wartości minimalnej, a jednak, jeśli zawierają zdańka lub słówka zahaczające o jakieś wzruszające nas wspomnienia, wtedy ów niewartościowy artystycznie utworek uzyskuje moc wzruszenia nas i nieraz z naszych oczu wyciska łzy" (Peiper 2000: 553). Jako przykłady tego rodzaju piosenek podawał śpiewane w filmie Warszawiankę (1831, sł. C.F. Delavigne, muz. K. Kurpiński) oraz Serce w plecaku (1933, sł. i muz. M. Zieliński). Nie wspominał natomiast - co znamienne - o napisanym przez Ważyka Marszu Pierwszego Korpusu (1943, muz. A. Bachracz), który pojawiał się w zakończeniu filmu, śpiewany przez maszerujących ulicami stolicy polskich żołnierzy.

\section{"Jasnołanność przybiera wygląd fałszu”}

Recenzja Zakazanych piosenek dokumentowała zainteresowanie Peipera rodzimą kinematografią powojenną. Jednak skupienie na tym medium, tak charakterystyczne dla całej formacji awangardowej, która od samego początku upatrywała w filmie sztuki przyszłości (Kluszczyński 1990), w powojennych realiach stawało się coraz trudniejsze, bo wchodziło na kurs kolizyjny z praktykami propagandowymi. Peiper świadomie unikał tego zderzenia, z tego względu wiele jego tekstów zachowało się w rękopisach, inne zaś wycofane zostały w ostatniej chwili z druku, jak to miało miejsce w przypadku recenzji Jasnych tanów (1947, reż. E. Cękalski), która nosiła wymowny tytuł Film zty. Była to de facto długa lista zarzutów, którym patronowało przekonanie, że artystyczna klęska wynikła w znacznej mierze z nieumiejętnego opowiedzenia dokonujących się w kraju przemian oraz ich wpływu na życie mieszkańców. Z perspektywy zwolennika procesów modernizacyjnych, za jakiego uważał się Peiper, był to kardynalny błąd, który prowadził do zerwania kluczowej dla konstruktywistycznego dyskursu więzi pomiędzy sztuką a zmianami społecznymi. Pierwsza miała konceptualizować drugie, wpisując je przy tym w ramy wielkiej narracji postępu, która scalała różne, pozornie niezwiązane ze sobą elementy. Tymczasem Cękalski kompletnie pominął ten związek i skupił się wyłącznie na społeczności wiejskiej, nie przedstawił natomiast dynamiki wkraczania powojennej rzeczywistości w życie mieszkańców prowincji. Z tego względu Peiper pisał, że „wiewy społeczne wdzierające się w atmosferę wsi nie mają w sobie prawdy życia”, dodając aforystyczną konkluzję: ,jasnołanność przybiera wygląd fałszu” (Peiper 2000: 460). 
Peiper nie był w tych zarzutach odosobniony. Film Cękalskiego powszechnie krytykowano ze względu na przesadnie propagandowy wydźwięk oraz niewyszukane rozwiązania kompozycyjne i stylistyczne (Urban 2015). Jednak recenzja Peipera nie ograniczała się wyłącznie do krytyki samego filmu, jej ostrze zwracało się także przeciw niejasnym mechanizmom funkcjonowania sztuki w społeczeństwie powojennym, o czym mowa była już w otwierającym całość akapicie: „Orkiestra prasowa wszystkimi swoimi instrumentami łaje twórców filmu, a publiczność, jak długo przebywa na terenie budynku kinowego, zachowuje milczenie, potem zaś, rozsypana na grupki, daje upust swemu oburzeniu". A zaraz potem zapytywał: „Czyżby sprawa kryła w sobie jakieś tajemnicze zło?” (Peiper 2000: 459).

Retoryczne pytanie odsyłało do spraw wykraczających poza ramy sztuki filmowej. Szerzej na ten temat pisał Peiper w szkicu poświęconym powojennej polskiej kinematografii, który na pierwszy rzut oka był próbą podsumowania jej dotychczasowych osiągnięć. W rzeczywistości sprawa była o wiele bardziej skomplikowana, bo tekst był popisem przenikliwości podsycanej przez dręczącą pisarza chorobę; pierwsza pozwalała na jasne wskazanie przyczyn słabości artystycznych, druga kazała pisać o rządzącej w upaństwowionym „Filmie Polskim” sitwie, która uniemożliwiała pracę w branży utalentowanym twórcom. Oskarżycielski ton hamowany był przez ostrożność, wynikającą z sytuacji komunikacyjnej: tekst miał ukazać się $\mathrm{W}$ „dzienniku wydawanym przez partię” i to właśnie ją wzywał pisarz do rozwiązania problemu. Dlatego zgłaszał pod jej adresem postulaty, których celem miało być podniesienie poziomu produkowanych w kraju dzieł, przygotował także projekt scenariusza filmu o tematyce wiejskiej, który nie doczekał się jednak realizacji.

Peiperowi pozostała bierna rola widza. Rosnący dystans do praktyk władzy, zwiększająca się presja czynników politycznych na sztukę, coraz bardziej pogłębiająca się choroba wszystko to wypychało go poza margines życia artystycznego, a jednocześnie sytuowało w roli uważnego obserwatora ówczesnych realiów. Czytane z takiej perspektywy pisma filmowe wydają się szczególnie „dokumentem jakiegoś pookupacyjnego zła” (Peiper 2000: 452), relacją z czasów, kiedy na ekranach i w salach kinowych gęstniała atmosfera podejrzliwości, którą wzmagał proces dewaluacji mowy.

\section{Śpiew i milczenie}

W zdeformowanych narracjach kronikarskich, tyradach filmowych speakerów, wywodach bohaterów filmów socrealistycznych i opowieściach „wyjaśniaczy” Peiper dostrzegał monotonny spektakl władzy. Wszystkie te głosy były symptomem dewaluacji oświeceniowych ideałów, z jakich wyrastał dyskurs konstruktywistyczny; wielkie opowieści o postępie oraz emancypacji tworzyły ramę, wewnątrz której wyraźnie wybrzmiewał optymizm cywilizacyjny, podsycany dodatkowo przez utopijne projekty epoki. Widziany z perspektywy wyznawcy oświeceniowych ideałów nazizm jawił się jako zaprzeczenie dziedzictwa l'Âge des Lumières, przekreślonego w imię diametralnie odmiennych haseł i wartości. Zupełnie inaczej prezentował się w tym względzie system radziecki, „katastrofa stalinizmu polegała na tym, że był on bezpośrednim dziedzicem oświecenia i reprezentował jego wewnętrzne zakłamanie" (Dolar 2015: 254). Krach był dotkliwy tym bardziej, że progresywistyczne narracje rozsypały się na zgiełk propagandowych głosów, których monotonność wynikała z faktu, że ich rolą nie było tworzenie spektaklu (jak w przypadku hitleryzmu), lecz wystąpienie przed Wielkim Innym historii (Dolar 2015: 253). 
Klęska postępu podsycała nostalgię. Jej sygnałem był powrót do czasów kina międzywojennego, który Peiper uzasadniał w swoich pismach przedsięwzięciami badawczymi. Nosił się z zamiarem przygotowania monumentalnej publikacji $Z$ zagadnień estetyki ekranowej, której zaplanowany z dużym rozmachem konspekt zawierał między innymi rozdziały: Polskie filmoznawstwo dawniejsze, Czas jako czynnik kina i ekranu, Budowa dramatu ekranowego, Montaż filmowy, Funkcja konfliktu w dramacie ekranowym, Filmowa sztuka aktorska, Stowo na ekranie, dźwięk na ekranie (Peiper 2000: 459). Zachowane teksty sugerują, że budowę gmachu wiedzy filmoznawczej rozpoczął od pracy nad ostatnimi dwoma spośród wymienionych zagadnień.

Kamieniem węgielnym tego gmachu była nostalgia. Jej ładunek był dostrzegalny wyraźnie nie tyle w tęsknocie za przeszłością, bo tę należało w czasach powojennych wyrażać ze sporą rozwagą, ile w specyficznym doborze analizowanego materiału. Dobrym przykładem jest tutaj szkic Gdy dziesiąta muza otrzymata dźwięk i stowo, w którym Peiper snuł rozważania na temat nowych form wyrazu, jakie zyskała sztuka kinematograficzna w momencie wprowadzenia do niej dźwięku. Za największą zdobycz w tym względzie uważał możliwość tworzenia przy pomocy montażu „ciągu” obrazów ukazujących ruch w „coraz to nowym wykroju przestrzeni”. Jako przykład takiego rozwiązania kompozycyjnego podawał sceny z filmu Świat się śmieje (Wiesiotyje rebiata, 1934) Grigorija Aleksandrowa oraz Milion (Le Million, 1931) René Claira. W pierwszym przypadku był to „marsz pastucha grającego na fujarce i otrzymującego coraz to nowych towarzyszy marszu”, w drugim: „część, w której szereg osób, ująwszy się za ręce, odbywa drogę po sieniach, schodach i korytarzach poddaszy, odbywa tę drogę krokiem tanecznym i wtóruje temu pochodowi śpiewem” (Peiper 2000: 535). Jednak rozważania na temat technik filmowych miały także inny wymiar, w obu przypadkach bohaterem analizowanych produkcji była niewielka zbiorowość, sytuująca się na antypodach nowoczesnego społeczeństwa, opiewanego niegdyś w konstruktywistycznych manifestach (Groys 2016). Zamiast idei nowoczesnego ładu, która dewaluowała się w komunistycznych projektach, na plan pierwszy wysuwały się tutaj jakości inne, wyraźnie zaznaczające się w słowach: „upajał mnie rytm narastania maszerującej gromady i rytm jej chodu, a jeden i drugi w harmonijnym związku z rytmem narastania odbywanej drogi” (Peiper 2000: 536). W tej retoryce harmonii i zgody pobrzmiewała wyraźna apoteoza życia opartego na relacjach bliskich tym, jakie opisywali Ferdynand Tönnies i Martin Buber, gdy przeciwstawiali „wspólnotę” — odpowiednio — „stowarzyszeniu” (Tönnies 1998 ) i „kolektywowi” (Buber 1992). Doświadczony nie tylko przez chorobę, ale także okrucieństwo wojny i przemoc totalitaryzmu pisarz również zwracał się w tę stronę, snując marzenie o autentycznych i niezniszczonych przez nowoczesność relacjach międzyludzkich.

Chóralny śpiew stanowił także antytezę monotonnych komunikatów władzy. Był figurą jednomyślności krańcowo odmiennej od tej, jaka dominowała w ówczesnej kulturze, coraz mocniej podporządkowanej „tyrańskiej mowie”. Lęk przed nią wyraźnie przenikał również do tekstów Peipera, zapewne z tego powodu rozważania na temat filmu barwnego rozpoczął od podszytego rezygnacją zastrzeżenia, które wiele mówiło o jego poczuciu alienacji w zdominowanej przez ideologię rzeczywistości: „W tej serii notatek zajmuję się przede wszystkim sprawami ekranowej barwy. Gdyby kiedykolwiek to, co tutaj piszę, ukazało się drukiem, niektórzy czytelnicy może pomówiliby mnie o formalizm. Niesłusznie”. I wyjaśniał, powołując się przy tym na swoje przedwojenne rozważania: „Zajmowanie się formą, nawet wyłącznie, nie zawsze pochodzi z formalizmu. Świadectwem pochodzenia jest rodzaj pojmowania formy. Dla mnie forma zawsze była «także treścią»” (Peiper 2000: 641). Utrzymane w tym 
tonie uzasadnienia zajęły jeszcze kilka akapitów, w których Peiper konsekwentnie przekonywał, że „ktoś powinien zajmować się sprawami, którymi ja się zajmuję. Nie wszyscy mają po temu skłonności i zdolności. Ja mam je. Rezultaty przynoszą czytelnikowi niemałe korzyści; wiem to, więc są społecznie pożyteczne" (641). Uchylanie potencjalnych zarzutów wieńczył klasyczny topos modestiae, mający na celu wyraźne podkreślenie różnicy między metodologią Peipera a wszystkim, co wiązało się z przedrostkiem „ideolo-” („lepiej, niż mógłbym ja to uczynić, roztrząsają i rozstrzygają te sprawy — ideologowie, ideonomowie i ideografowie"; Peiper 2000: 641).

\section{W stronę pozaludzkiego}

Odwrót od „tyrańskiej mowy” był procesem konsekwentnym. W późniejszych tekstach zarysowała się analogia między wycofaniem się Peipera z aktywnego życia literackiego a coraz większym zainteresowaniem, jakie okazywał pozawerbalnej ekspresji. Rozważania na temat barwy i dźwięku koncentrowały się na tych aspektach kinematografii, które z jednej strony były względnie mało zależne od presji władzy, z drugiej natomiast podlegały ciągłemu doskonaleniu: „Kto czuje moce, prężące się w sztuce ekranowej [...], ten śledzi uważnie [...] każdy postęp, jaki filmowa dźwiękowość uzyskuje w technice fabrycznego wyrobu lub w sztuce reżyserów" (Peiper 2000: 585). Współpraca techniki z twórczą wolą człowieka dawała na tym polu coraz bardziej zaawansowane rezultaty, lecz śledzenie tego procesu było zaledwie cieniem progresywizmu międzywojennego. Resztki wiary w postęp dopalały się w „formalistycznych" wywodach, które Peiper uznawał za sferę względnie wolną od ideologicznej przemocy.

Jej nośnikiem był język. Znamienna pod tym względem była recenzja Wesotych kumoszek $z$ Windsoru (1950, reż. G. Wildhagen), w której Peiper zastanawiał się, czy brak mowy przez pierwsze dziesięć minut filmu wynikał z koncepcji reżysera, błędu technicznego, czy może — i ten domysł był najbardziej frapujący — „zarząd wydziału dystrybucji filmowej uznał za właściwe wyłączyć początek taśmy dźwiękowej, aby język niemiecki, który w czasie wojny wrył się tak okrutnie w pamięć Polaków, a po wojnie oznaczał skrót najokrutniejszych wspomnień, aby ten język nie uderzał od razu w polskie uszy" (Peiper 2000: 568). Podejrzenia pisarza nie wynikały jedynie z dręczącej go choroby, być może wplynęła na nie też znajomość ówczesnych praktyk Filmu Polskiego, który nie zawsze respektował integralność dzieł, jakie prezentowane były podczas seansów ${ }^{3}$. Jednak w tym domyśle najciekawszy wydaje się sugerowany związek między językiem i przemocą, wyraźnie korespondujący z niechęcią do „tyrańskiej mowy”, od której Peiper odcinał się przecież wielokrotnie. Być może z tego wzglę-

3 W szkicu na temat Pustelni parmeńskiej (1948, reż. Christian-Jaque) pisal na ten temat:

Kończy się pierwsza seria krótko, bez żadnych przygotowań finałowych. Koniec ten ma w sobie szybkość i lekkość i odbija dodatnio od przeciąganych ponad miarę zakończeń. [...] Wyszedłem z kina zachwycony. Dowiedziałem się później, że zachwycający koniec nie pochodzi od reżysera, lecz... powstał u nas, w Polsce. Kierownicy Państwowego Przedsiębiorstwa „FF” uznali taśmę Pustelni parmeńskiej za zbyt długą na jeden seans i postanowili podać ją naszym widzom w dwóch seriach.

Z tego względu w innych recenzjach mniej szablonowe zakończenia filmów traktował z pewnym dystansem, na przykład w tekście na temat Dziennika marynarza (1942, reż. S. Salkow) pisał:

Happy-end w postaci małżeństwa [...] tutaj nie istnieje. Jeżeli nie słyszymy wyroku uwalniającego, to nawet taki happy-end nie istnieje. Byłoby to świadome i ideologiczne przeciwstawienie się «szkole». Ale może to «Film Polski» odciąt finał? (Peiper 2000: 591, 576) 
du w rozważaniach na temat filmu dźwiękowego tak dużo uwagi poświęcał pozasłownym sposobom konstruowania znaczenia.

Prowadziło to niekiedy do przenikliwych interpretacji. W recenzji Marsylianki (1938, reż., J. Renoir) zwracał uwagę na otwierającą film scenę zmiany warty, kiedy „żołnierskie obcasy wtupujące się w pałacową posadzkę” miały charakteryzować „dryl podpierający monarchię absolutną” (Peiper 2000: 585). W podobny sposób pisał o „szurgocie obcasów Ludwika XVI, gdy bezradny i bezsilny zamyśla się nad manifestem księcia Brunszwiku”, dostrzegając w tych efektach sygnały przyszłych zdobyczy, dzięki którym „sztuka ekranowa będzie sposobami dźwiękowymi niewypowiedzianie ekspresyjnymi charakteryzowała człowieka, jego czyny i przeżycia” (Peiper 2000: 585). Pomyślne próby w tym zakresie widział też między innymi w Mtodym Puszkinie (1937, reż. A. Narodistski) oraz Symfonii pastoralnej (1946, reż. J. Delannoy). W tym drugim przypadku pisał wręcz, że „stuki obcasów pastorskich w klinicznym korytarzu są najpełniejszym chyba i jako ekspresja najlepszym osiągnięciem tego rodzaju" (Peiper 2000: 595).

Gest ustąpienia pola „ideologom” miał także inny rezultat. Rozważania na temat dźwięku i barwy przesuwały zainteresowania Peipera w stronę filmowych reprezentacji przyrody, które traktował jako sprawdzian dla możliwości ówczesnej kinematografii, z różnym stopniem doskonałości przedstawiającej świat natury. W szkicu poświęconym Pieśni tajgi (1948, reż. L. Pyriew) stwierdzał z emfazą, że należy z dużą uwagą śledzić te próby, ponieważ to właśnie na tym terenie „rozstrzygnie się wygląd ekranu przyszłości” (Peiper 2000: 631). Dlatego pisał o nich z patosem, niekiedy do wywodów wkradały się też elementy liryczne, które przywodziły na myśl jego twórczość poetycką z minionych dekad, jak choćby wieńcząca anaforyczne wyliczenie puenta: „śledzimy naszą bohaterkę [tj. barwę] na kwiatach, na igliwiach i na wodach, a w końcu na dymie kolejowej lokomotywy, który przesłania i odsłania twarze czworga ludzi odjeżdżających w radość" (Peiper 2000: 631). Zwracał także baczną uwagę na ekranowe reprezentacje zwierząt, podkreślał „zaszczytnie wyeksponowanie stworzeń” w Wesotych kumoszkach z Windsoru (Peiper 2000: 571), zaś na marginesie Wiosny w Sakenie (1951, reż. N. Saniszwili) pisał o pasącym się bydle: „ten składnik sceneryjny zwraca na siebie uwagę oryginalnością. Chyba nie mylę się: te woły i krowy mają w sobie niespotykaną w innych filmach bierność, oporność... Jakby - na równi z ciemnymi zacofańcami wsi - i one nie wierzyły w glebę Sakenu” (Peiper 2000: 608). Natomiast tekst o Powrocie Lassie (1943, reż. F. M. Wilcox) zakończył spostrzeżeniem, że tytułowa bohaterka „wyróżnia [się] [...] odezwaniami się. Mogłoby wydawać się, że ten pies to mazgaj. A jednak gdy sytuacja wymaga ataku, atakuje brawurowo. Kiedy zaś szczek oznacza prawdziwą ważkość chwili, gdy trzeba podnieść głos, szczek jego brzmi donośnie i dźwięcznie jak żaden inny” (Peiper 2000: 636).

Zwrot w stronę pozaludzkiego miał również inny wymiar. Wskazuje na to ostatni z przywołanych tekstów, który w zamierzeniu Peipera stanowił część większego cyklu artykułów na temat filmu barwnego. Jednak to nie sprawy związane z kolorystyką zajmowały tutaj najwięcej miejsca, bo ponad połowa rozważań poświęcona została analizie zachowań tytułowej bohaterki, do czego zresztą zachęcał scenariusz. Wychylenie w stronę pozaludzkiego miało w tym wypadku dramatyczny podtekst, bo opowieść o losach psa, który ze względu na biedę został sprzedany przez właścicieli, a następnie powracał do nich przez pogrążony w ekonomicznym kryzysie kraj, nabierała w wywodach pisarza specyficznego znaczenia. Peiper wysuwał na plan pierwszy nie tyle wieńczącą opowieść reintegrację, która była niezbywalnym elementem tego rodzaju fabuł (Fudge 2007: 37), ile raczej postać Lassie; pisał o niej 
z mieszanką podziwu, empatii i antropomorfizacji, wymieniając długą listę zalet bohaterki, w której „nie było wcale psiej służalczości”, kuszona przez osoby postronne „nie dbała o smakołyki, nie sprzedawała się”, zaś do gospodarzy domu „nie odnosiła się jak do panów, lecz jak do istot, które kocha”, wreszcie: „nie była na niczyich usługach” i „przychodziła z pomocą tym, których kocha” (Peiper 2000: 635). Recenzja przeistaczała się w apoteozę, która akcentowała - co znamienne - nie heroizm Lassie, lecz jej poczucie niezależności, godności oraz umiejętność istnienia w ramach wspólnoty: „Związek między nią a ludźmi opiera się na nierozerwalnej łączności sprzęgającej ze sobą życie obu stron. Nie widzi dla siebie innej możliwości bytowania, jak tylko w łączności z nimi” (Peiper 2000: 635). Harmonijna wizja koegzystencji, o jakiej pisał wcześniej Peiper przy okazji analizy innych filmów, została w tym przypadku przesunięta nie w nostalgicznie odmalowaną przeszłość, lecz w stronę pozaludzkiego, gdzie poszukiwał alternatywy dla rozpleniającej się wokół „tyrańskiej mowy”.

\section{Bibliografia}

Buber Martin (1992), Ja i Ty. Wybór pism filozoficznych, przeł. J. Doktór, Instytut Wydawniczy

PAX, Warszawa.

Dolar Mladen (2006), A Voice and Nothing More, The MIT Press, Cambridge.

- (2015), Polityka gtosu, przeł. P. Bożek, G. Nowak, „Teksty Drugie”, nr 5.

Fazan Jarosław (2010), Od metafory do urojenia. Próba patografii Tadeusza Peipera, Wydawnictwo UJ, Kraków.

Fudge Erica (2007), The Dog, the Home and the Human, and the Ancestry of Derrida's Cat, „Oxford Literary Review”, Vol. 29.

Groys Boris (2008), Art Power, The MIT Press, Cambridge.

- (2016), Installing Communism [w:], tegoż, In the Flow, Verso, London.

- (2010), Stalin jako totalne dzieto sztuki, przeł. P. Kozak, Sic!, Warszawa.

Hendrykowska Małgorzata (2011), Film polski wobec wojny i okupacji. Tematy, motywy, pytania, Wydawnictwo Naukowe UAM, Poznań.

Jakubowska Wanda (reż.) (1953), Żotnierz zwycięstwa, Wytwórnia Filmów Fabularnych w Łodzi. Krasucki Eryk (2006), Przepis na bohatera narodowego albo o tym, dlaczego Karol Świerczewski nie zostat gwiazdą kina (perypetie scenariusza „Żotnierza zwycięstwa” Wandy Jakubowskiej z 1953 roku), „PRL w Filmie. Biuletyn IPN”, nr 7.

Kluszczyński Ryszard Waldemar (1990), Film — sztuka Wielkiej Awangardy, PWN, Warszawa. - (1983), Kino i film w teorii sztuki Tadeusza Peipera [w:] tegoż, Problemy awangardy, red. Kłak T., Naukowe UŚ, Katowice.

McGowan Todd (2008), Realne spojrzenie, Wydawnictwo Krytyki Politycznej, Warszawa. 
Peiper Tadeusz (2000), W'ród ludzi na scenach i na ekranie, t. 2, opr. K. i J. Fazanowie, Wydawnictwo Literackie, Kraków.

Tatarczyk-Gubała Monika (2015), Wanda Jakubowska: od nowa, Wydawnictwo Krytyki Politycznej, Warszawa.

Tönnies Ferdinand (1988), Wspólnota $i$ stowarzyszenie. Rozprawa o komunizmie i socjalizmie jako empirycznych formach kultury, przeł. M. Łukasiewicz, Warszawa.

Urban Gabriel Piotr (2015), „Burza nad tanami”. "Jasne tany” (1947) na tamach czasopisma „Film”, „Roczniki Humanistyczne”, nr 2.

Ważyk Adam (1947), Pierwszy petny metraż krajowy, „Kuźnica”, nr 4. 